\title{
Radiolarian Age Constraints of Mid-Cretaceous Black Shales in Northern Tunisia
}

\author{
Ben Fadhel Moez ${ }^{1}$, Soua Mohamed ${ }^{2}$, Zouaghi Taher' ${ }^{1}$ \\ Layeb, Mohsen ${ }^{3}$, Amri Ahlem ${ }^{1}$ and Ben Youssef Mohamed ${ }^{1}$ \\ ${ }^{1}$ CERTE, Technopole de Borj Cédria, \\ ${ }^{2}$ Entreprise Tunisienne d'Activités Pétrolières, \\ ETAP-CRDP 4 Rue des Entrepreneurs, 2035 la Charguia II, \\ ${ }^{3} I S M P$, Tunis, \\ Tunisia
}

\section{Introduction}

Mid-Cretaceous pelagic deposits outcropping in Northern Tunisia include organic-rich beds locally associated with high abundance of radiolarian microfauna, which are interpreted as the signature of the two global oceanic anoxic events OAE1 and OAE2 (Talbi, 1991; Saïdi \& Belayouni; 1994; Caron et al., 1999; Amédro et al., 2005, Heldt et al., 2008; Khazri et al., 2009; Soua et al., 2009; Robascynski et al., 2010; Ben Fadhel et al., 2011). Several studies have stated the close association between organic-rich sediments and radiolarian in the Atlantic and Tethyan realms (Marcucci-Passerini et al, 1991; O’Dogherty, 1994; Erbacher \& Thurow, 1998; Danelian et al., 2004, 2007).

In North African margins, the radiolarian biostratigraphy have focused upon radiolarianbearing Jedidi Formation which has been thoroughly discussed by Cordey et al, (2005) and Boughdiri et al, (2007). The first attempts at dating radiolarian series in Northern Tunisia show that radiolarian associated with carbonate-siliceous beds, have yielded useful diagnostic radiolarian assemblages (Cordey et al., 2005; Soua et al., 2006; Ben Fadhel et al., 2010).

Albian and Cenomanian-Turonian black shales of Northern Tunisia were considered to have good generative oil source rock (Layeb, 1990; Saidi \& Belayouni, 1994; Bechtel et al., 1998; Ben Fadhel et al., 2011). In this overall context, the restudy and high-resolution biostratigraphy of Albian black shale beds of Lower Fahdene Formation and C/T cherty beds of organic-rich Bahloul Formation outcropping in Northern Tunisia domain have yielded well-preserved and age-diagnostic radiolarians species.

The aim of this paper is to: 1) give new illustrations of radiolarian taxa recovered from albian pelagic deposits of north african margins 2) establish a direct age of black shales using radiolarian assemblages 3 ) compare the radiolarian assemblages with time equivalent investigated in tethyan and east Pacific domains.

\section{Geological setting}

The area of investigation is located in Northern Tunisia (Fig. 1). Three sections are selected in this study on the basis of occurrence of organic and radiolarian-rich layers: 
1. The Jebel Srassif area (Fig. 1a) is located in the northwestern extremity of the 'Dome Belt', a complex structure linked to Triassic extrusions and strike-slip faults. According to Chikhaoui et al., (1991) and Chikhaoui \& Turki (1996), the observed structural complexity was the result of the extensive tectonic movement, which led to the extrusion of Triassic evaporites during the Albian-Aptian period. Consequently, halokinetic and tilted blocks movements are responsible for the horst and- graben architecture. The so-called 'tectonic corners', described by the previous authors, are induced by the reactivation of strike slip faults during the Tertiary compressive phase.

The Jebel Srassif section belongs to the subsiding basin of the Mellegue 'paleograben' (Chikhaoui et al., 1991) bordered by two structural highs: Koumine to the west and Nebeur to the east.

Cretaceous successions are characterized by a thick pile of Aptian to Campanian pelagic sequences, which are affected by multiple non-depositional unconformities and condensed layers (Chikhaoui, 1988)

2. The Fadeloun-Garci-Mdeker structure (fig.1b) in which belongs the Jebel Garci section, is composed of three anticlines, trending North South and considered as the northern prolongation of the N-S axis (Saadi, 1990). The anticlines are separated from the Atlasic domain by the Zaghouan thrust, which its North-eastern part becomes south-verging, commonly defined as the Chérichira-Kondar thrust (Khomsi et al., 2004).

The Cretaceous sedimentation was under the control of syn-sedimentary faults trending N140-160 reflected by chaotic and gravitational deposits (Saadi, 1991). Early Cretaceous successions show northward, reduced thickness and affected by hiatus and extreme condensations in Hammam Zriba (Saadi, 1990). The motion of a corridor trending north-south by N140-160 faults has led to the compartmentalization of the seafloor in losangic basins (Saadi, 1991).

During the Valanginian - Barremian time span, theses basins were supplied by siliciclastic deposits while condensed sedimentation occupied uplifted horsts (Biely et al., 1973; Saadi et al., 1994)

3. The Oued Kharroub section (Fig. 1c) is located in the Atlas domain (Northern and Central Tunisia), characterized by various facies of Cenomanian-Turonian transition (CT) deposits, including benthic fauna-rich carbonates e.g. Zebbag Formation by Burollet (1956) and Gattar Formation by Boltenhagen and Mahjoub (1974) and organic-rich black shales with pelagic fauna (e.g. Bahloul Formation by Burollet, 1956) respectively of shelf and slope in the southern margin of the Tethyan realm. During this period and since the Jurassic, this domain has been influenced by the opening of the Tethyan palaeosea, its deepening as well as its southern margin migration. Generally speaking, the Bargou area, connected palaeogeographically to central Tunisia, is characterized by (1) emerged palaeohighs displaying gaps and discontinuities (Turki, 1985) and (2) subsiding zones affected by deep-water sedimentation. This area is dominated by $\mathrm{N} 140^{\circ}$ and $\mathrm{N} 70^{\circ}$ trend faults limiting several blocks. Cretaceous sedimentation varies on both sides. Its structural evolution may be summarized as follow : (1) during the late Jurassic to early Cretaceous, the area was subjected to a major extensional phase that delimited horst and graben systems (Martinez \& Truillet, 1987) (2) In the uppermost Aptian, a regional compressional pulsation affecting the north-African platform had resulted from a transpressional scheme (Ben Ayed \& Viguier, 1981) (3) New NNE-SSW trend anticline structures appeared attested by the Albian Fahdene Formation onlap features on the reefal aptian Serj deposits in subsurface (Messaoudi \& Hammouda, 1994) or upper 
Aptian - Albian unconformity in outcrops (Ouahchi et al., 1998). (4) During the Albian, the geodynamic evolution is marked by the sealing of lower Cretaceous structures during an extensional phase that persisted to form graben systems promoting organicrich and siliceous strata deposition throughout upper Cenomanian to Lower Turonian times (Soua et al., 2009). The major faults in this area are represented by $\mathrm{N} 140^{\circ}$ and $\mathrm{N} 70^{\circ}$ trend features. The Bahloul thickness is significantly variable in this area. It may varies from $10 \mathrm{~m}$ to $40 \mathrm{~m}$ in thickness (Layeb \& Belayouni, 1989; Soua \& Tribovillard, 2007). Uniquely, in this area, the top of the Bahloul represents many cenomanian olistolith levels (Soua et al., 2006) marking syndepositional tectonic activities (Turki, 1985).

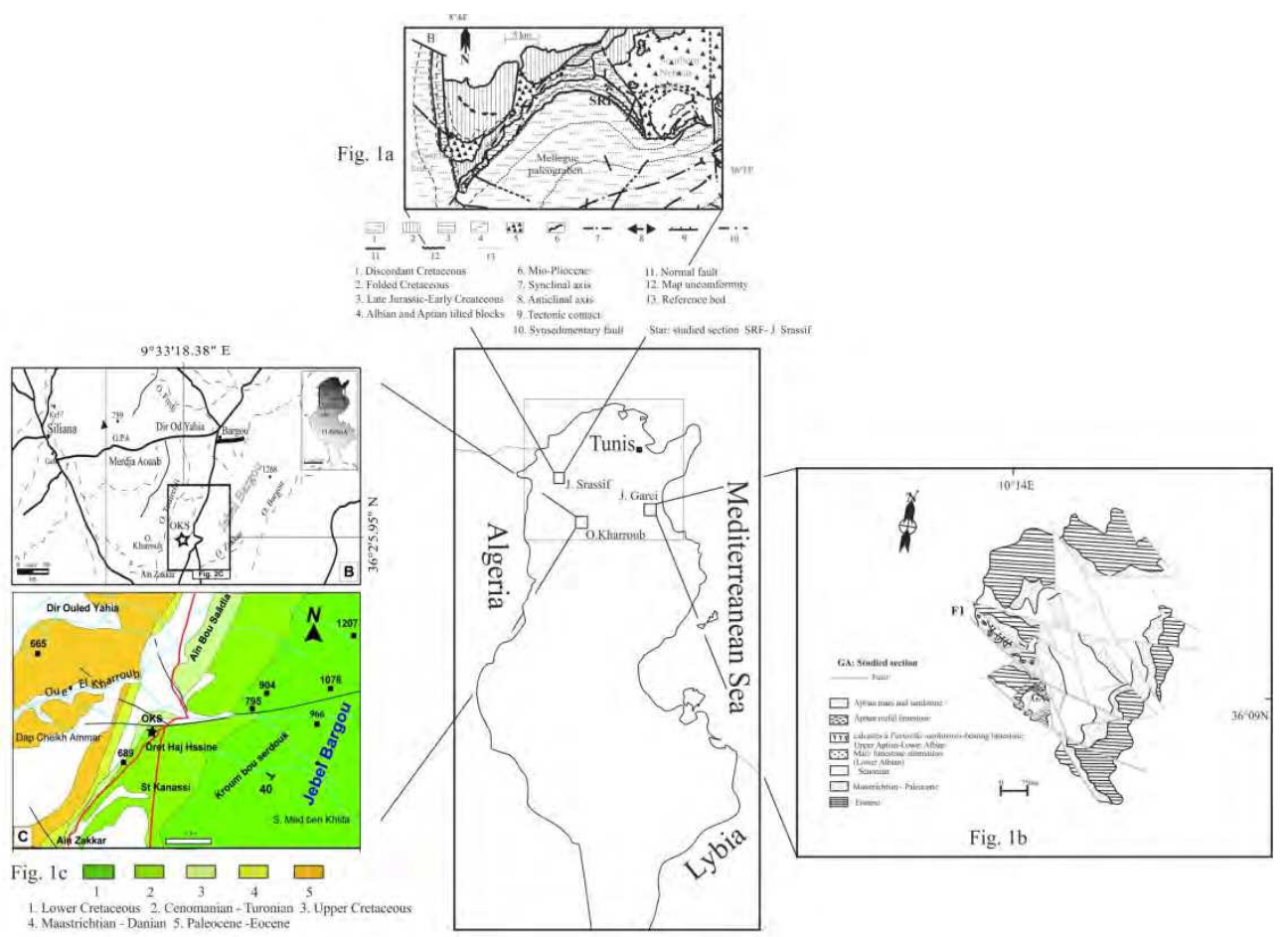

Fig. 1. Geological map of the studied sections (After Chikhaoui et al., 1991; Meddeb, 1986)

\section{Result}

\subsection{Jebel Garci section}

The condensed section of Jebel Garci (Fig. 2) begins with orbitolinids-rich green to gray clay alternating with discontinuous sandy limestone beds which are attributed to the Hameima Formation. The clay intervals have also provided fragments of rudist and bryozoans (GA1). The upper part contains olistolites deposits that gradually pass to a reefal limestone which is outlined at the top by burrowed hardground.

The next successions (GA9 - GA23) which correspond to the "Allam" Member consist of centimeter-thick grey to dark laminated limestone bed and organic-rich black marl intervals. 
Upwards, the succession becomes rhythmic and the marly intervals increase in thickness in opposition to limestone beds. The microfauna content yields depauperate planktic foraminiferal assemblages and radiolarian rich microfauna.

Fractures related to a strike slip fault outlining the black hales unit are onlapped by a marly intervals and gray limestone beds alternation (GA24-GA27).

The organic-rich beds (GA17 - GA 23) have released a moderately to well-preserved and age-diagnostic radiolarian species. Twenty nine species were recorded in the studied section.

The radiolarians appear with few discrete taxa within GA6 level. It provides an assemblage composed of Holocryptocanium barbui Dumitrica, Spongostichomitra elatica (Aliev), Pseudoeucyrtis hanni (Tan), Archeodictyomitra vulgaris Pessagno, Thanarla brouweri (Tan), Stichomitra simplex (Smirnova and Aliev), Angulobracchia portmanni Baumgartner, Thanarla pacifica Nakaseko and Nishimura. They become diversified and abundant within GA7. It yields an association of Dictyomitra aff. gracilis (Squinabol), Dictyomitra communis Squinabol, Dictyomitra montisserei (Squinabol), Pseudodictyomitra lodogaensis Pessagno, Thanarla praeveneta Pessagno, Archaeodictyomitra aff. A. vulgaris Pessagno, Hiscocapsa sp., Thanarla aff.pulchra (Squinabol), Spongostichomitra elatica (Aliev), Thanarla brouweri (Tan), Angulobracchia portmanni Baumgartner, Stichomitra simplex (Smirnova and Aliev), Stichomitra communis Squinabol

GA15 sample provided very diversified and abundant radiolarian population. It is composed by Dictyomitra montisserei (Squinabol), Holocryptocanium barbui Dumitrica Pseudodictyomitra lodogaensis Pessagno, Stichomitra simplex (Smirnova and Aliev), Pseudoeucyrtis hanni (Tan), Diacanhocapsa sp., Hiscocapsa grutterinki (Tan) Angulobracchia portmanni Baumgartner, Stichomitra communis Squinabol, Pseudodictyomitra paronai (Aliev), Cryptamphorella conara (Foreman)

GA18 provided Dictyomitra gracilis (Squinabol), Thanarla conica (Squinabol)

The upper part of black shales (G17-23), composed by rhythmic bundles of limestone and marl beds, is characterized by a decrease of radiolarian abundance. The sample GA20 has released a radiolarian assemblages composed of Thanarla brouweri (Tan), Spongostichomitra phalanga O' Dogherty, Pseudodictyomitra paronai (Aliev), Dictyomitra communis Squinabol, Holocryptocanium barbui Dumitrica, Pseudodictyomitra lodogaensis Pessagno, Dictyomitra gracilis (Squinabol), Dictyomitra montisserei (Squinabol), Spongostichomitra elatica (Aliev), Pseudodictyomitra paronai (Aliev)

Although the uppermost beds have yielded (GA24-27) benthic foraminiferal-rich assemblages, we identified well-preserved radiolarian population (GA24) composed of Pessagnobrachia rara (Squinabol), Stichomitra communis Squinabol, Dictyomitra montisserei (Squinabol), Cryptamphorella conara (Foreman), Holocryptocanium barbui Dumitrica, Pseudodictyomitra lodogaensis Pessagno, Torculum coronatum (Squinabol), Xitus spicularius (Aliev), Obeliscoites vinassai (Sqinabol), Hiscocapsa asseni (Tan), Thanarla pulchra (Squinabol), Dictyomitra communis Squinabol, Hiscocapsa grutterinki (Tan)

Marly interval of the top GA27 have released an assemblage of Holocryptocanium barbui Dumitrica, Stichomitra simplex (Smirnova and Aliev), Pseudodictyomitra paronai (Aliev), Dactyliosphaera maxima (Pessagno)

\subsection{Jebel Srassif section}

The base of Jebel Srassif section (Fig. 3) which constitutes the "Marnes Moyennes" Member, consists of 130 meter-thick alternations of grey marl and limestone, which become dark and laminated at the top. A cyclic marl/limestone bundles $(10 \mathrm{~m})$ can be distinguished having an 
Legend

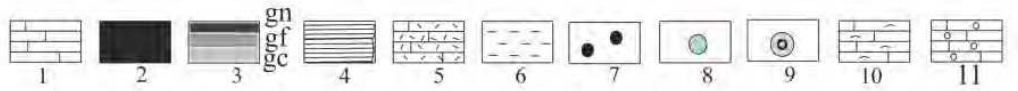

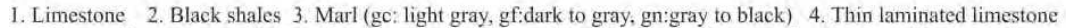

5. Siliceous limestone 6. Shales 7. Iron oxide level 8. Olistolith layers 9. Ammonites horizon 10. Reefal limestone 11. Sandy limestone

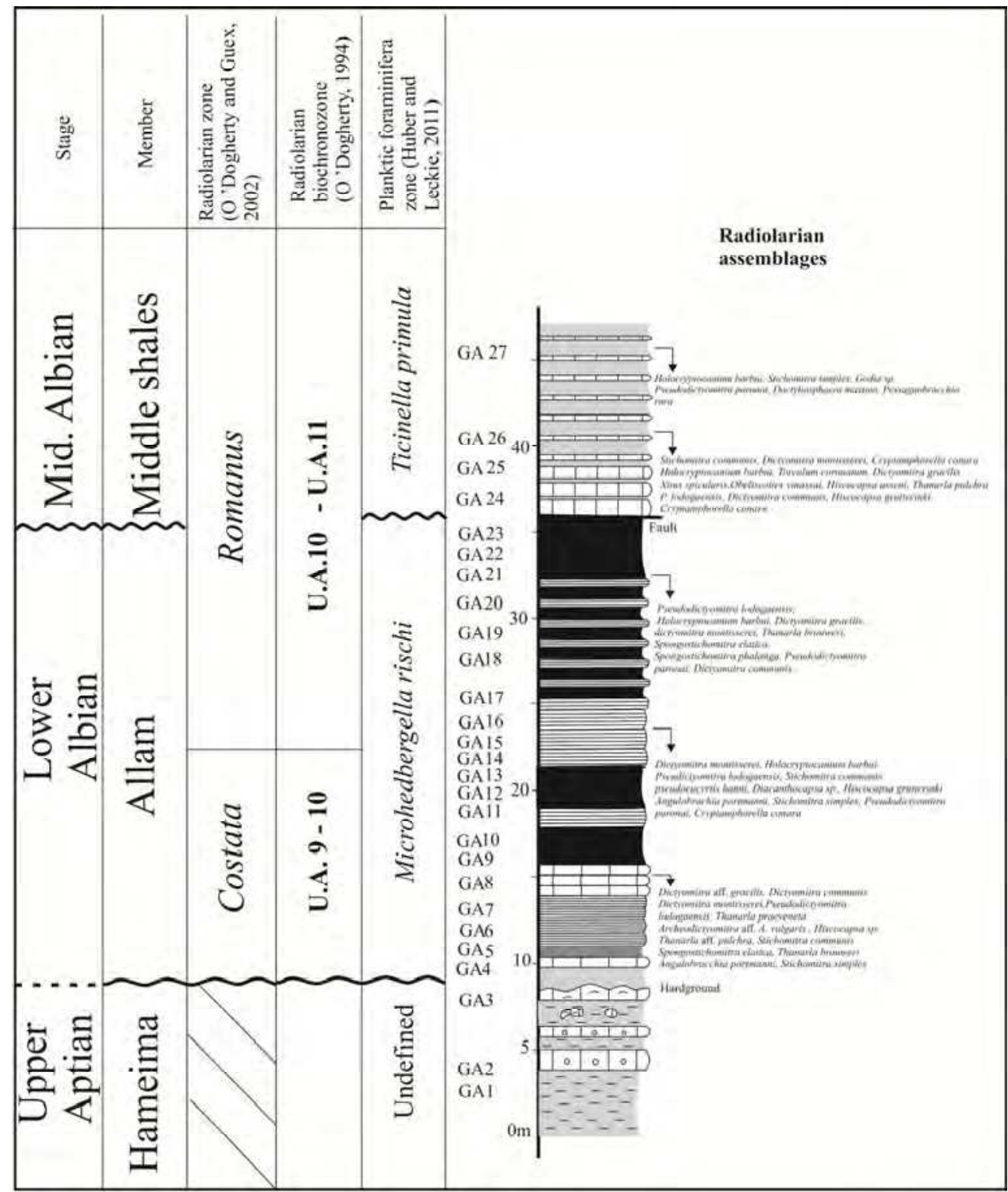

Fig. 2. Jebel Garci section 
organic and radiolarian-rich mudstone texture. It is capped by a thick organic-rich limestone bed $(20 \mathrm{~m})$ characterized by bituminous odor and yellowish color in patina. This level corresponds to the Mouelha member (Burollet, 1956). The 40 meters of the top consist of an alternation of grey limestones and dark grey-ochre marls yielding septarian nodules characterizing the Defla member. They are overlain by a succession of lenticular limestone beds and grey marl of Azreg member $(50 \mathrm{~m})$.

Three samples were selected, based on the good preservation of the faunal assemblages. Among 35 radiolarian morphotypes, only 23 species were figured. Biostratigraphic analysis of the fossil record and planktic foraminifer's zones (Fig. 3, and Plates 1 and 2) correlation allow us to distinguish the following three radiolarian assemblages:

1. The sample 37 has provided a diversified radiolarian fauna with the co-occurrence of Dictyomitra montisserei (Squinabol), Obeliscoites perspicuus (Squinabol), Tubilustrium transmontanum O'Dogherty, Dictyomitra gracilis (Squinabol), Holocryptocanium barbui Dumitrica, Stichomitra aff. navalis O'Dogherty, Cryptamphorella conara (Foreman), Torculum dengoi (Schmidt-Effing), Stichomitra communis Squinabol, Torculum coronatum (Squinabol), Distylocapsa micropora (Squinabol), Patellula verteroensis (Pessagno), Godia concava $(\mathrm{Li} \& \mathrm{Wu})$.

2. Radiolarian assemblage recovered from sample 62 is highly diversified at the top of Mouelha blackshales. Likewise, it records an acme of species belonging to Hagiastridae and Cavaspongiidae taxa. This interval shows the co-occurrence of Dispongotripus acutispinus Squinabol, Dactyliosphaera maxima (Pessagno), Pessagnobrachia sp., Cavaspongia euganea (Squinabol), Cryptamphorella conara (Foreman), Pessagnobrachia rara (Squinabol), Dorypyle communis (Squinabol), Pseudodictyomitra paronai (Aliev), Pseudodictymitra sp., Torculum coronatum (Squinabol), Holocryptocanium tuberculatum Dumitrica, Distylocapsa micropora (Squinabol), Obeliscoites perspicuus (Squinabol), Dactyliosphaera acutispina Squinabol, Dictyomitra gracilis (Squinabol), Thanarla spoletoensis O'Dogherty, Dactyliosphaera lepta (Foreman), Patellula verteroensis (Pessagno), Savaryella novalensis (Squinabol), Savaryella quadra (Foreman), Pessagnobrachia fabianii (Squinabol), Stichomitra communis Squinabol, Holocryptocanium barbui Dumitrica, Xitus aff. spicularius (Aliev), Torculum coronatum (Squinabol), Crolanium aff. spineum (Pessagno),

3. 3. Sample 68 is characterized by the abundance of cryptocephalic nassellaria (Holocryptocanium). Moreover, we notice the first occurrence and bloom of Mallanites triquetrus. This interval shows the co-occurrence of Xitus mclaughlini (Pessagno), Hexapyramis pantanelli Squinabol, Mallanites triquetrus (Squinabol), Thanarla spoletoensis O'Dogherty, Dictyomitra montisserei (Squinabol), Godia concava (Li \& Wu), Cryptamphorella conara (Foreman), Torculum coronatum (Squinabol), Cavaspongia euganea (Squinabol), Distylocapsa micropora (Squinabol), Dactyliosphaera maxima (Pessagno), Holocryptocanium barbui Dumitrica, Dactyliodiscus longispinus (Squinabol), Dispongotripus acutispinus Squinabol.

\subsection{Oued Kharroub section}

The outcrop (Fig. 4) is composed mainly by dark clayey limestone and organic-rich black shales with abundant planktic foraminifera. These organic-rich deposits include siliceous beds with abundant radiolarians, an equivalent to "Livello Bonarelli" bed marker (Marcucci Passerini et al, 1991; Salvini and Marcucci Passerini, 1998; Premoli-Silva et al, 1999; Scopelliti et al, 2004; Musavu-Moussavou et al, 2007) 


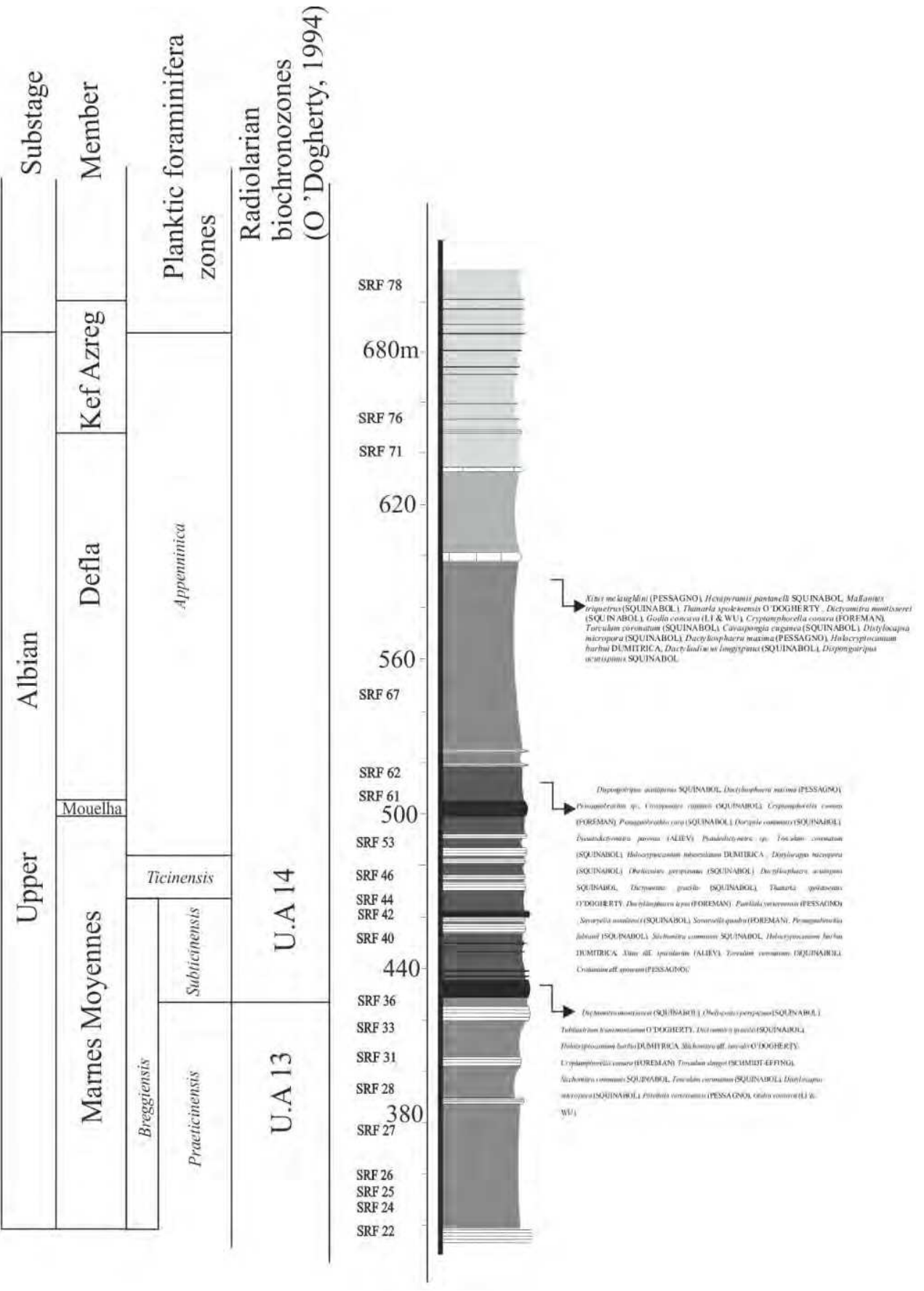

Fig. 3. Jebel Srassif section 


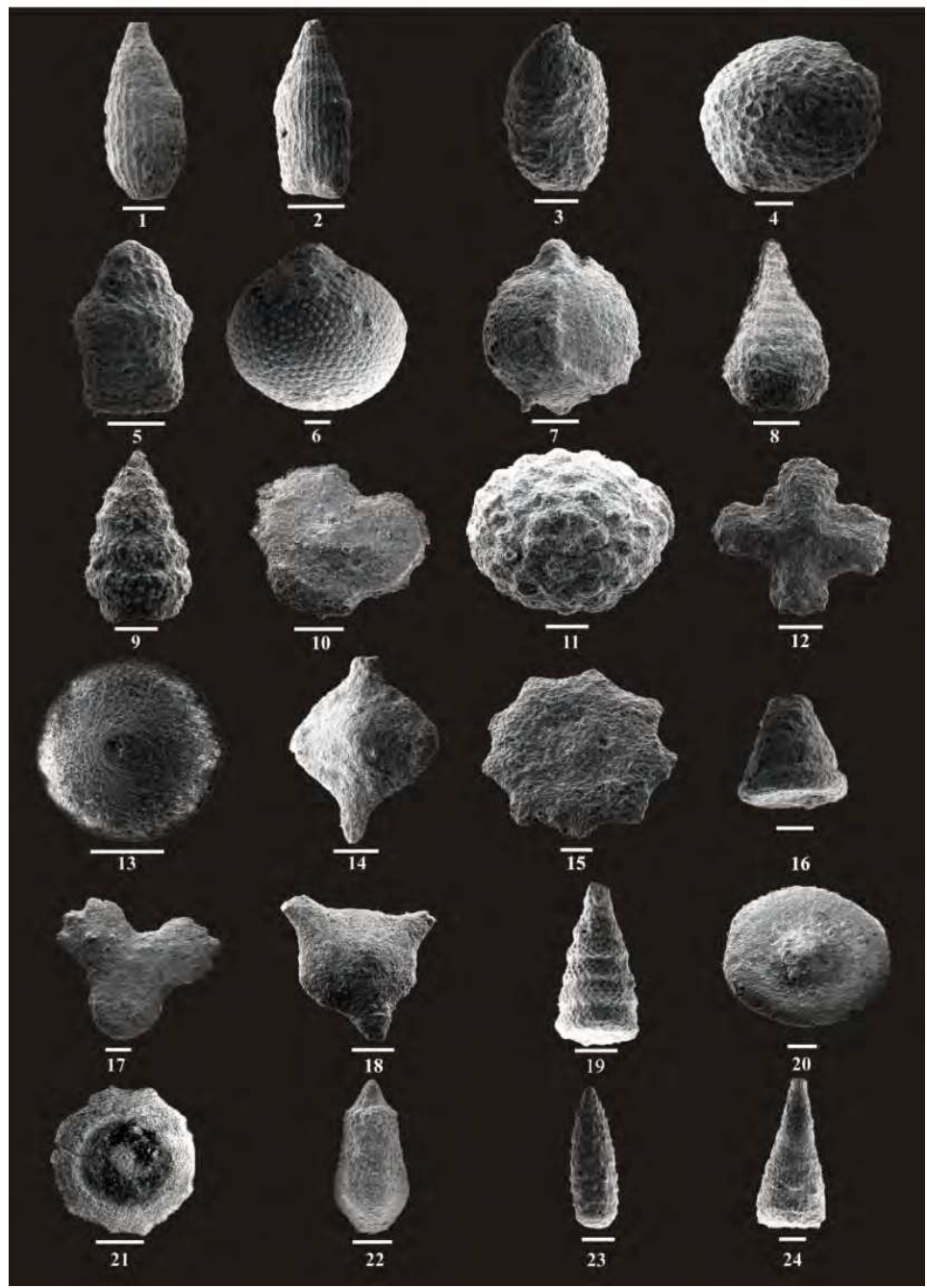

Plate 1.1 - Dictyomitra gracilis (SQUINABOL), scale bar: 50m, sample 62. 2 - Dictyomitra montisserei (SQUINABOL), scale bar: $50 \mathrm{~m}$, sample 68.3 - Tubilustrium transmontanum O'DOGHERTY, scale bar: 50m, sample 37. 4 - Holocryptocanium barbui DUMITRICA, scale bar: 50m, sample 37.5 - Stichomitra aff. navalis O'DOGHERTY, scale bar: 50m, sample 37.6 Cryptamphorella conara (FOREMAN), scale bar: $50 \mathrm{~m}$, sample 37.7 - Mallanites triquetrus (SQUINABOL), scale bar: 100m, sample 68.8 - Dictyomitra gracilis (SQUINABOL), scale bar: 100m, sample 62. 9 - Xitus aff. spicularius (ALIEV), scale bar: 100m, sample 62. 10 Dispongotripus acutispinus SQUINABOL, scale bar: 100m, sample 62. 11 - Holocryptocanium tuberculatum DUMITRICA, scale bar: 50m, sample 62. 12 - Savaryella quadra DUMITRICA, scale bar: 100m, sample 62. 13 - Patellula verteroensis (PESSAGNO), scale bar: 150m, sample 37. 14 Dactyliosphaera lepta (FOREMAN), scale bar: 50m, sample 62. 15 - Dactyliodiscus longispinus (SQUINABOL), scale bar: 50m, sample 68. 16 - Torculum dengoi (SCHMIDT-EFFING) Scale bar: 
50m, sample: 37.17 - Pessagnobrachia sp., scale bar: 100m, sample 62. 18 - Cavaspongia euganea (SQUINABOL), scale bar: 100m, sample 62. 19 - Stichomitra communis SQUINABOL, scale bar: 50m, sample 62. 20 - Dactyliosphaera maxima (PESSAGNO), scale bar: 100m, sample 62. 21 Godia concava (LI \&WU), scale bar: 100m, sample 37. 22 - Torculum coronatum (SQUINABOL), scale bar: 150m, sample 62. 23 - Crolanium aff. spineum (PESSAGNO), scale bar: 100m, sample 62. 24 - Obeliscoites perspicuus (SQUINABOL), scale bar: 100m, sample 62.

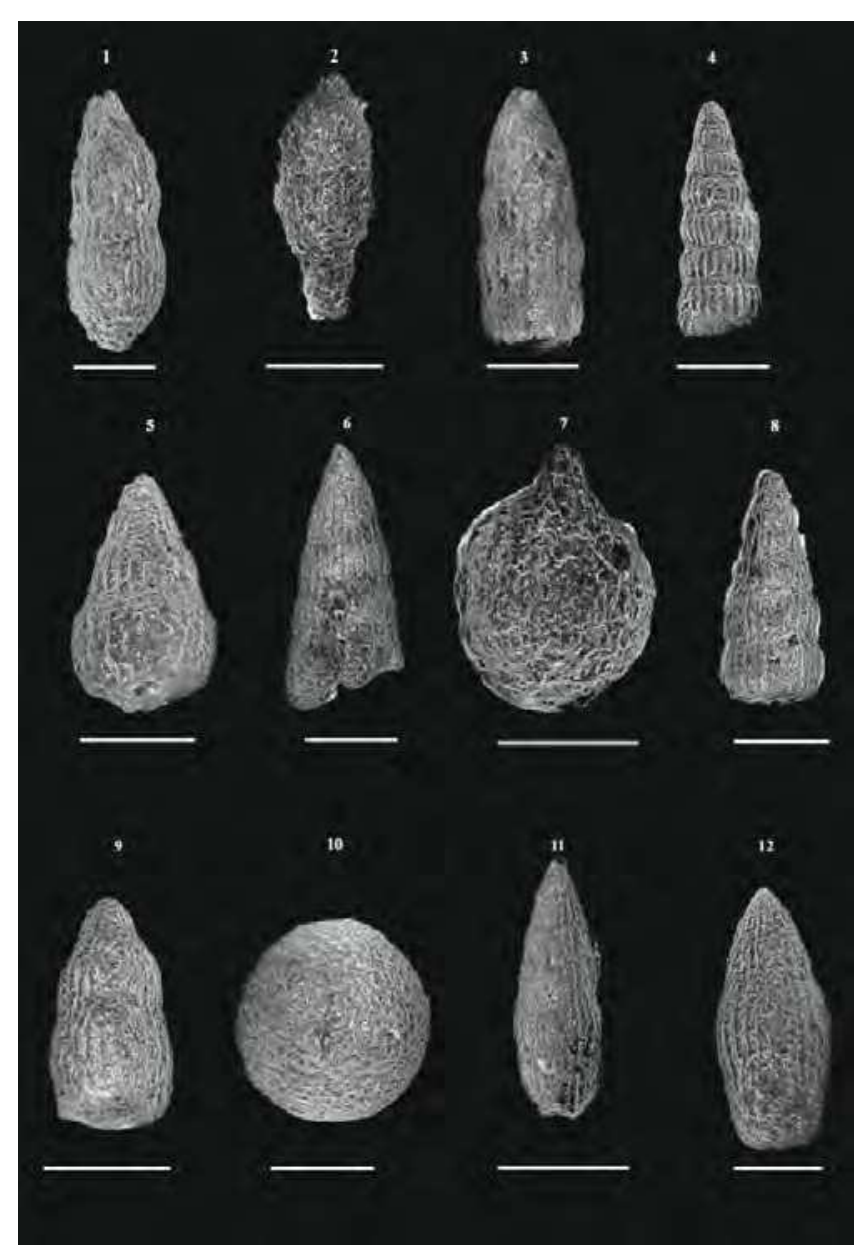

Plate 2. 1 - Dictyomitra gracilis (SQUINABOL), 100 $\mu$ m, GA18. 2 - Pseudoeucyrtis hanni (TAN), $100 \mu \mathrm{m}, \mathrm{GA15} .3$ - Dictyomitra montisserei (SQUINABOL), 100 $\mu \mathrm{m}, \mathrm{GA} 21.4$ - Pseudodictyomitra lodogaensis PESSAGNO, 100 $\mu \mathrm{m}, \mathrm{GA21} .5$ - Thanarla praeveneta PESSAGNO, 100 $\mu \mathrm{m}, \mathrm{GA8} 8.6$ Archeodictyomitra aff. vulgaris PESSAGNO, 100 $\mu \mathrm{m}, \mathrm{GA} 8.7$ - Hiscocapsa sp. 100 $\mu \mathrm{m}, \mathrm{GA} 8.8$ Dictyomitra communis (SQUINABOL), 100 $\mu \mathrm{m}$. GA8. 9 - Thanarla aff.pulchra,( SQUINABOL), $100 \mu \mathrm{m}, \mathrm{GA} 8.10$ - Holocryptocanium barbui DUMITRICA, 100 $\mu \mathrm{m}, \mathrm{GA} 20.11$ - Dictyomitra

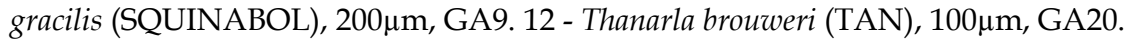


A total of twenty five of radiolarian species are recognized belonging to nassellarians and spumellarians with maximum of eighteen (18) species in sample OKS 11. Their differential stratigraphical range and relative abundance allow to distinct two successive assemblages ( $\mathrm{R}_{\mathrm{I}}$ and $\mathrm{R}_{\mathrm{II}}$ ) through the C-T transition.

Although, the studied radiolarian species do not exhibit a good potential for biostratigraphic dating, the section is calibrated either by foraminifers and ammonites.

The $R_{\text {II }}$ assemblage spans the upper part of the OAE-2 interval and the organic-poor deposits overlying this interval. It is characterized by a decrease trend of the nassellarian relative abundances (from $87 \%$ to $42 \%$ ). Therefore, maybe dissolution or bad preservation conducted to the absence of this group close to the base of the upper half of the section, across the OKS40-OKS45 samples interval. Many species show rapid and gradual disappearing following a stepwise-like pattern (e.g. Guttacapsa sp., Spongostichomitra elatica, Novixitus sp., Stichomitra stocki, Mita gracilis, Pseudodictyomitra pseudomacrocephala, Thanarla pacifica D. montisserei).

About the associated spumellarians, several species from the $\mathrm{R}_{\mathrm{I}}$ assemblage persisted more or less long time (e.g. Archaeocenosphera aff. vitalis, Crucella messinae, Praeconocaryomma lipmanae, Rhopalosyringium hispidum Pyramispongia glascockensis Pessagno., Cavaspongia euganea (Squinabol),, C. Californiaensis Campbell and Nishimura, Pseudoeucyrtis spinosa (Squinabol), Archaeocenosphaera? mellifera O'Dogherty,). Nevertheless, very few species of nassellarians first occurred across the upper half part of the studied section. All these species are represented by dwarf and poorly preserved specimens.

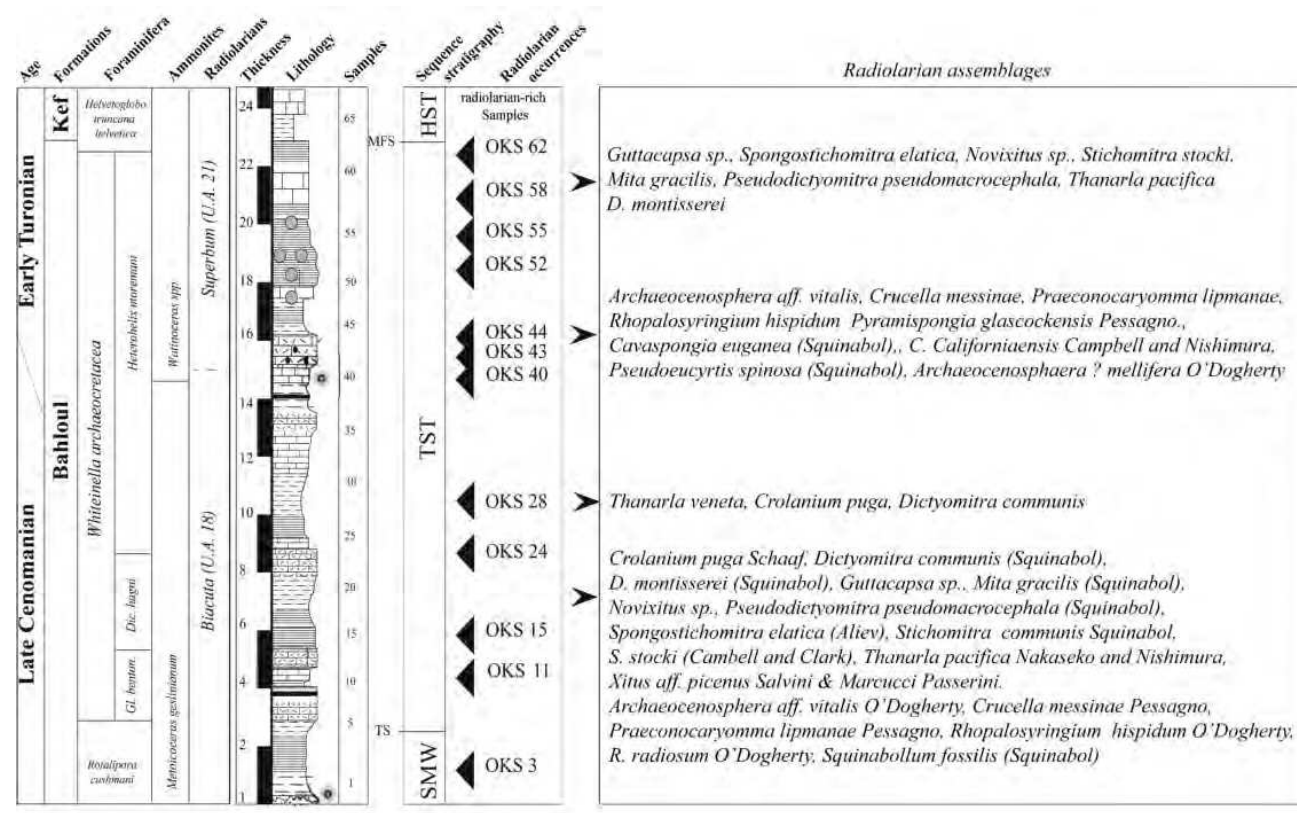

Fig. 4. Oued Kharroub section 


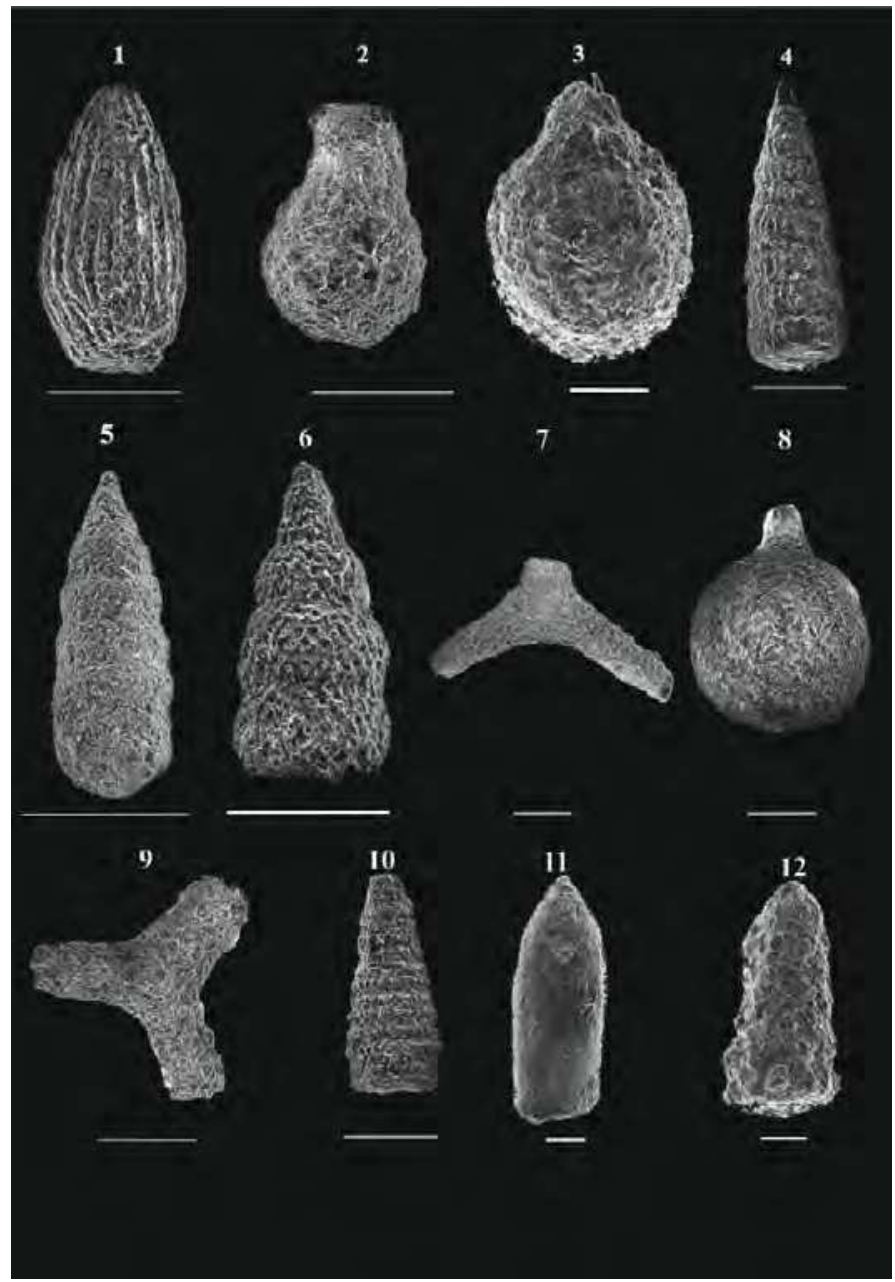

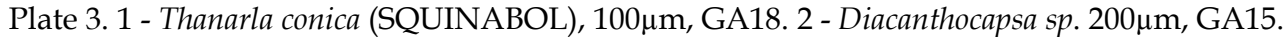

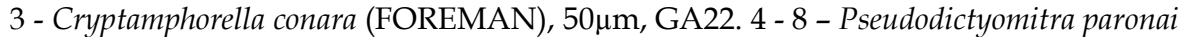

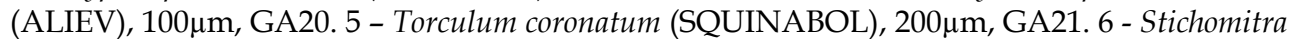
simplex (SMIRNOVA et ALIEV), 100 $\mu \mathrm{m}, \mathrm{GA15} .7$ - Angulobracchia portmanni

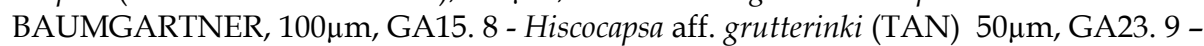
Pessagnobrachia rara (SQUINABOL), 100 $\mu \mathrm{m}, \mathrm{GA27.} 10$ - Xitus spicularius (ALIEV), 100 $\mu \mathrm{m}$,

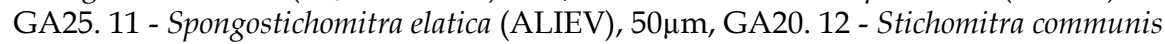
SQUINABOL, $50 \mu \mathrm{m}$, GA8. 


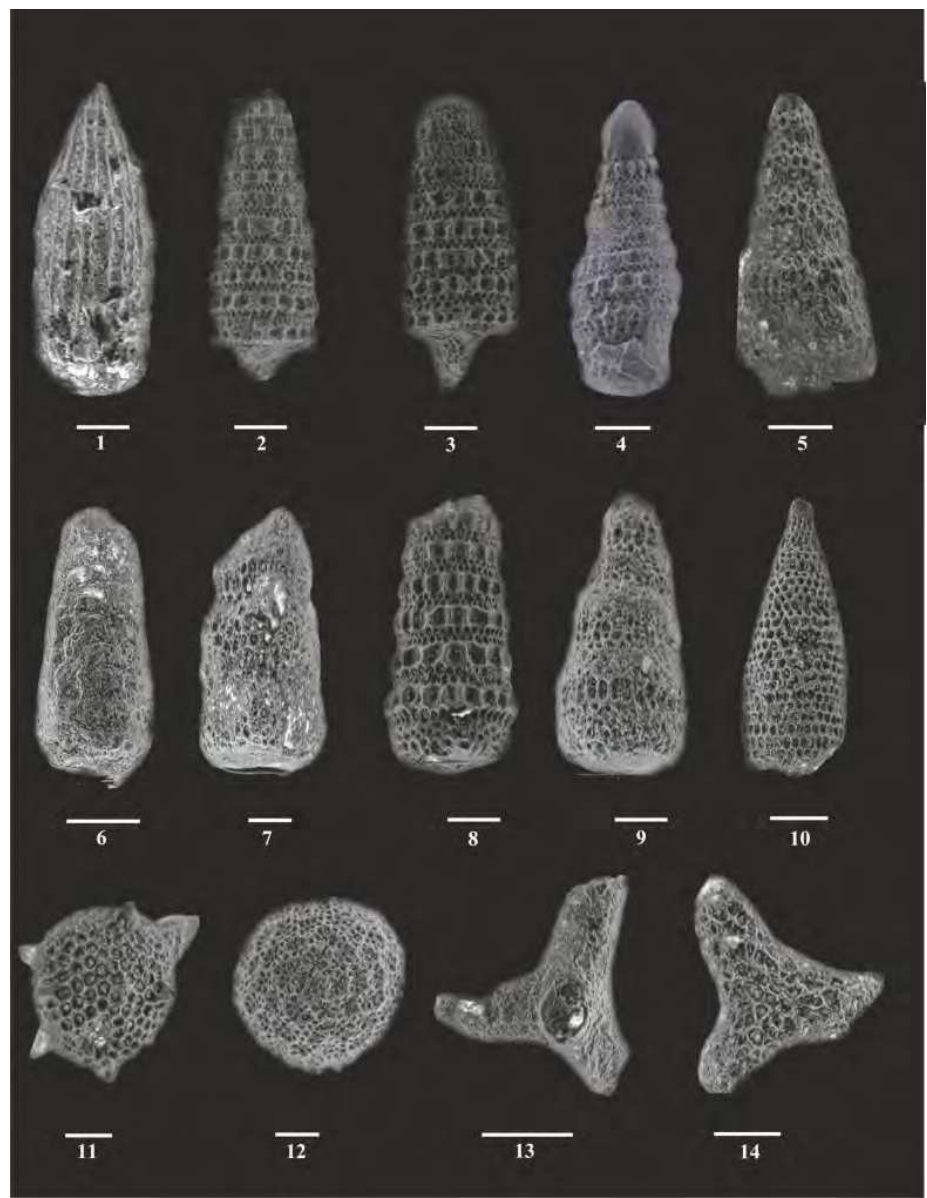

Plate 4. 1- Mita gracilis (?) (Squinabol), scale bar: 100, OKS-40. 2- Novixitus (?) sp., scale bar: 100, OKS-43;3-Novixitus sp. Scale bar: 100, OKS-42. 4- Pseudodictyomitra pseudomacrocephala (Squinabol), scale bar: 100, sample OKS-11. 5- Guttacapsa sp. Scale bar: 50, OKS-24. 6indetermined species, scale bar: 100, OKS-24. 7- indetermined species, scale bar: 50, sample OKS-58. 8- Pseudodictyomitra sp. Scale bar: 100, OKS-15. 9- Xitus aff. picenus Salvini and Marcucci Passerini, scale bar: 50, OKS-40. 10- Phalangites (?) sp. Scale bar: 50, OKS-58; 11Squinabollum fossile (Squinabol), scale bar: 50, OKS-28. 12- Archaeocenosphaera? mellifera O’Dogherty, scale bar: 50, OKS-62. 13- Cavaspongia sp., scale bar : 50, OKS-3. 14- Cavaspongia californiaensis Pessagno, scale bar: 50, OKS-58.

\section{Discussion}

Detailed analysis of radiolarian assemblages allows us to attribute a biostratigraphic framework for the organic-rich beds. In the following section, we used zonal scheme proposed by O'Dogherty (1994) for tethyan realms. The age-diagnostic assemblages are discussed and compared with time equivalent investigated in adjacent tethyan domains. 
O'Dogherty (1994) proposed a radiolarian zonation for the Albian based on Unitary Associations. He described for the Upper Albian to the base of the Cenomanian the Spoletoensis zone divided into three radiolarian subzones: the Romanus, Missilis and Anisa subzones. Bak (1995) established a radiolarian zonation $(\mathrm{H}$. barbui $-\mathrm{H}$. geysersensis) for the Albian-Cenomanian of northern Tethyan domains, based on the co-occurrence of Holocryptocanium barbui DUMITRICA, Holocryptocanium geysersensis PESSAGNO, Novixitus weyli SCHMIDT-EFFING, Squinabollum fossile (SQUINABOL), Crymptamphorella macropora DUMITRICA, Hemicryptocapsa tuberosa DUMITRICA

The first appearance of B. breggiensis, recorded within Upper Albian basal intervals, coincides with first appearance of radiolarian species Tubilustrium transmontanum O'DOGHERTY, which is confined with the upper part of the Romanus subzone (O'Dogherty, 1994). An assemblage containing Stichomitra navalis and Torculum coronatum was recorded also within this subzone.

Babazadeh \& de Wever (2004) described a radiolarian assemblage yielding the cooccurrence of Dictyomitra gracilis, Holocryptocanium barbui and Dictyomitra montisserei and assigned it to Middle-Late Albian age. Nevertheless, the presence of T. dengoi, whose first appearance coincides with the Missilis - Anisa subzones boundary (O'Dogherty, 1994), allows rejuvenating the assemblage age.

Samples recovered from the succession overlying the Mouelha Member blackshales show an assemblage composed of Cryptamphorellla conara Dumitrica, Pessagnobrachia sp., and Thanarla spoletoensis O'DOGHERTY, which correspond to the lower part of the Appenninica zone and the middle part of the Anisa subzone of O'Dogherty (1994). Although the coexistence of $D$. lepta, Stichomitra communis and Patellula verteroensis is assigned to early Late Cenomanian age (Erbacher, 1998), this assemblage possibly characterize the Late Albian taking into account the presence of $D$. maxima whose last occurrence is coeval with the base of Anisa subzone (O'Dogherty, 1994).

Samples recovered from basal beds (GA2-GA6) show high abundance of Pseudodictyomitra lodogaensis and contain some early Cretaceous taxa from Turbocapsula Zone such as A.portmanni and Th. pacifica (O' Dogherty, 1994; Erbacher and Thurow, 1998; Danelian et al., 2007; Michalik et al., 2008). Thus, a late Aptian age of these beds could not hitherto be ruled out.

According to Erbacher \& Thurow (1998), the first occurrence of Pseudodictyomitra lodogaensis coincides with the upper part of G. algerianus Zone. Its last occurrence coincides with the Aptian-Albian boundary and the first occurrence of Mita gracilis (= Dictyomitra gracilis). This taxon is also reported from the Albian to Cenomanian deposits of the Atlantic domain, California and Pacific realms (Thurow, 1988; Karminia, 2006; Palechek et al., 2010).

It is possible that black shale unit of Jebel Garci could underlines the Aptian-Albian boundary. In fact, Danelian (2008) have reported the presence of Thanarla praeveneta from the Upper Aptian - Lower Albian bed which occurs in GA7 beds underlying the black shale successions.

On the other side, Slazcka et al., (2009) described an assemblage containing Angulobracchia portmanni Baumgartner, Dictyomitra communis (Squinabol), Hiscocapsa asseni (Tan), Pseudodictyomitra lodogaensis Pessagno, Pseudoeucyrtis hanni (Tan), almost similar to GA7 taxa. These authors attributed the assemblage to Costata zone that is confined to UA6-9 biochronozones of mid to late Aptian age (O'Dogherty, 1994).

It is noteworthy to point the coexistence of Albian species in all samples such as D.montisserei and D.gracilis with Aptian taxa particularly in GA7, GA 15 and GA26. 
In that score, an assemblage recovered from Mid Cretaceous outcrops of Northern Tethys margins was described by Danelian et al., (2007), shows the co-occurrence of $P$. lodogaensis, Dictyomitra gracilis, Thanarla brouweri, Archaeodictyomitra aff.vulgaris assigning it to the early Albian UA10-11 biochronozone. Danelian et al (2004) consider that an early Albian age of Dercourt Member cannot be ruled out despite the presence of Angulobracchia portmanni and pseudoeucyrtis hanni characteristic of U.A.9. These species are observed hitherto within assemblage from GA15, associated with Dictyomitra montisserei.

Kurilov \& Vishnevskaya (2011) described an assemblage extracted from Early Cretaceous outcrops of Pacific domain that does not differ from GA21. It contains Thanarla brouweri, Pseudodictyomitra paronai, Pseudodictyomitra lodogaensis, Holocryptocanium barbui, Dictyomitra cf. montisserei, Dictyomitra communis, and Dictyomitra gracilis indicating an early Albian age.

The sample GA26 has provided an assemblage characterized by high abundance of Hiscocapsa asseni, co-occurring with D.gracilis and D.montisserei. It lies with the UA10 biochronozone of Romanus zone (O’Dogherty, 1994; Danelian et al., 2004).

We suggest that lower part of black shale intervals could be assigned to the upper part of Costata zone (GA5 - GA14) based on the presence of Aptian taxa (i,e. Angulobracchia portmanni, Pseudoeucyrtis hanni). The lower part of this zone coincide with the first occurrence of Microhedbergella praeplanispira planktic foraminifera. Whereas the top coincide with the last occurrence of Angulobracchia portmanni and Pseudoeucyrtis hanni associated with a relative increase in abudance of Archaedictyomitrae and Williriedellidae families.

The Romanus zone (GA14 - GA27) show the dominance of high diversified nassellarian species. The assemblage recovered from GA17 is composed of Thanarla brouweri, Archaeodictyomitra montisserei, Thanarla conica which is attributed to the middle Albian Mallanites romanus subzone (U.A. 10 -11 biochronozone) (O'Dogherty, 1994; Danelian et al, 2004). However, the first occurrence of Ticinella primula planktic foraminifera is recorded 24 $\mathrm{m}$ above GA17 bed. Thus, we suggest that lower part of Romanus zone may be attributed to the Early Albian.

Studies on Cenomanian - Turonian boundary interval show that deposition of radiolarian, organic-rich sediment and large positive carbon isotopic excursion are coeval with extreme fertility conditions and correspond to a large-scale proxy that indicate a hypersiliceous period (Premoli Silva et al, 1999; Racki \& Cordey, 2000)

The Bonarelli equivalent in Tunisia is commonly known by the Bahloul Formation (Burollet, 1956). In the Bargou area, the Bahloul Formation shows organic-rich intervals interbedding cherty and radiolarian limestone layers (Layeb and Belayouni 1999, Soua and Tribovillard, 2007)

Although the $\mathrm{C} / \mathrm{T}$ boundary interval outcropping in the Tunisian realm was extensively studied by planktic foraminifera and ammonite biostratigraphy (Maamouri et al, 1994; Nederbragt and Fiorentino, 1999; Abdallah et al., 2000; Amédro et al, 2005), radiolaria assemblages have provided a useful tool for age calibration and subdivision of $\mathrm{C} / \mathrm{T}$ organicrich beds in this study.

Two black shale levels were identified in Oued Kharroub section:

1. The first lies with the lower part of Withinella archaeocretacea planktic foraminifera zone, above the highest occurrence of Rotalipora cushmani

2. The second coincides with the middle part of Heterohelix moremani zone

The calibration of these levels is based on age-diagnostic radiolarian recovered from biosiliceous limestone beds (Fig. 4). 
The OSK 24 yields an assemblage composed of Rhopalosyringium radiosum O'Dogherty, Praeconocaryomma lipmanae Pessagno, Acaeniotyle vitalis O'Dogherty Rhopalosyringium hispidum O'Dogherty. The three first taxa have been described by Bak et al (2005) and attributed them to the late Cenomanian - early Turonian. Erbacher (1998) attribute Rhopalosyringium radiosum to the early Turonian, but later Musavu-Moussavou and Danelian (2006) expand its range to late Cenomanian. The assemblage contains Xitus picenus Salvini and Marcucci - Passerini which its range do not exceed the Silviae Zone of Bonarelli (O’Dogherty, 1994; Salvini \& Marcucci-Passerini, 1998). Consequently, we assign the lower black shale beds (OKS 11) to the late Cenomanian and to upper part of Silviae Zone [U.A 18 biochronozone of O’Dogherty (1994)]

Many authors have stated the occurrence of Archaeocenosphaera mellifera O'Dogherty within Turonian strata of Boreal and northern Tethyan domains (Bandini et al., 2006; Smreckova, 2011). In East Pacific domain, this taxon, associated with C. californaensis and Pyramispongia glascockensis PESSAGNO, is recorded within the Silviae Zone of late Cenomanian age (Bragina, 2009). Salvini \& Marcucci-Passerini (1998) stated that C. californiaensis occurs only in the base of upper assemblage $C$ of Bonarelli Level which lies with the base Superbum Zone defined by O'Dogherty (1994). In the Atlantic domain, the last occurrence of $C$. californiaensis is recorded in the late Cenomanian just beneath the organic-rich beds related to the OAE2 (Musavu-Moussavou and Danelian, 2006). Taking into account the paleogeographic similarities between northern and southern Mediterranean Tethys margins, the radiolarian assemblage recovered from OKS44 level could be correlated with upper assemblage (Superbum Zone) of Bonarelli level in Central Italy. Thus, the second black shale lie with the upper part of Biacuta subzone of late Cenomanian age, if we take into consideration the position of turonian Watinoceras spp. ammonite (Amédro et al., 2005)

\section{Conclusion}

Biostratigraphic investigations of Albian and C/T boundary intervals in Northern Tunisia show that organic-rich beds are generally associated with high abundance of radiolarian fauna.

Age constraint of organic-rich sediments is established and correlated with biochronozones of O'Dogherty (1994). In the light of these results, we deduce that:

1. Black shale interval of Jebel Garci which is embedded within the "Allam" Member is assigned to the early Albian U.A.10 biochronozone. However, the latest Aptian could not be excluded for the lower part.

2. Late Albian organic-rich beds of Jebel Srassif including cyclic limestone/marl beds of "Marnes Moyennes" and Mouelha Members lie with the boundary interval between U.A. 13 and U.A. 14 biochronozones.

3. Two black shale levels embedded within Bahloul Formation are probably of late Cenomanian age and confined with the U.A.18 biochronozone. The first occurrence of turonian Watinoceras spp. ammonite is recorded $70 \mathrm{~cm}$ above the second black shale bed (OSK40)

It seems that distribution of radiolarian assemblages of albian and cenomanian-turonian boundary intervals shows some difference from those of Atlantic and east Pacific domains. Preservation index and range discrepancies of some radiolarian species could affect the subdivision resolution. Further studies on radiolarian distribution assemblages and relationships with environmental changes during Mid-Cretaceous time are needed to establish paleogeographic reconstructions of southern tethyan margins. 


\section{Acknowledgments}

We thank Drs Moncef Saidi and Hedia Bessaies from ETAP center research for giving all facilities needed for SEM photographs. Authors gratefully acknowledge Dr. Imran Ahmad Dar, Editor-in-chief, for accepting the publication of this work.

\section{References}

Abdallah, H., Sassi, S., Meister, C., \& Souissi, R. (2000). Stratigraphie séquentielle et paléogéographie à la limite Cénomanien-Turonien dans la région de Gafsa-Chotts (Tunisie centrale). Cretac. Res., vol.21, No. 1, pp. 35-106, ISSN 01956671

Amédro F., Accarie H., \& Robaszynski F. (2005). Position de la limite Cénomanien-Turonien dans la Formation Bahloul de Tunisie centrale : apports intégrés des ammonites et des isotopes du carbone ( $\delta 13$ C). Eclogae Geologicae Helvetiae, vol. 98, No. 2, pp. 151167, ISSN 0012-9402

Babazadeh, S. A. \& De Wever, P. (2004a). Radiolarian Cretaceous age of Soulabest radiolarites in ophiolite suite of eastern Iran. Bulletin de la Société Géologique de France, Vol. 175, No.2, pp. 121-129, ISSN 0037-9409

Bak, M. (1995). Mid Cretaceous radiolarians from the Pieniny Klippen Belt, Carpathians. Poland. Cretaceous Research, vol. 16, No. 1, pp. 1-23, ISSN 01956671

Bak, M., Bak, K. \& Ciurej, A. (2005). Mid-Cretaceous spicule-rich turbidites in the Silesian Nappe of the Polish Outer Carpathians: radiolarian and foraminiferal biostratigraphy. Geological Quarterly, vol, 49, No. 3, pp. 275-290, ISSN 1641-7291

Bandini, A.N, Baumgartner, P.O. \& Caron, M. (2006). Turonian Radiolarians from Karnezeika, Argolis Peninsula, Peloponnesus (Greece). Eclogae geol. Helv. 99 Supplement, Vol.2, pp.1-20, ISSN 0012-9402

Biely, A., Memmi, L., Salaj, J. \& (1973). Le Crétacé inferieur de la région d'Enfidaville. Découverte d'Aptien condense, Livr. Jub. M. Solignac, Ann. Min. Geol., vol. 26, pp.169-1 78, ISSN: 03300013

Bechtel, A., Savin, S.M. \& Hoernes, S. (1999). Oxygen and hydrogen isotopic composition of clay minerals of the Bahloul Formation in the region of the Bou Grine zinc-lead ore deposit (Tunisia): evidence for fluid-rock interaction in the vicinity of salt dome cap rock. Chemical Geology, Vol. 156, Issues 1-4, pp. 191-207, ISSN 0009-2541

Ben Ayed, N. \& Viguier, C. (1981). Interprétation structurale de la Tunisie atlasique. CRAS Paris, t 292 série II pp. 1445-1448, ISSN 16310713

Ben Fadhel, M., Layeb, M. \& Ben Youssef, M. (2010). Upper Albian planktic foraminifera and radiolarian biostratigraphy (Nebeur - northern Tunisia). Comptes Rendus Palevol, vol. 9, No. 3, pp. 73 - 81, ISSN 16310713

Ben Fadhel, M., Layeb, M., Hedfi, A. \& Ben Youssef, M. (2011). Albian Oceanic Anoxic Events in northern Tunisia: Biostratigraphic and geochemical insights. Cretaceous Research vol. 32, No. 6, pp. 685-699, ISSN 01956671

Boltenhagen, C. \& Mahjoub, M. N. (1974-79). Divers rapports inédits sur la géologie du Cretacé moyen de Tunisie centrale. Archives SEREPT.

Boughdiri, M., Cordey, M., Sallouhi, H., Maalaoui, K., Masrouhi, M. \& Soussi, M. (2007). Jurassic radiolarian-bearing series of Tunisia: biostratigraphy and significance to western Tethys correlations. Swiss Journal of Geoscience, vol. 100, No.3, pp. 431-441, ISSN 16618726. 
Bragina, L.G. (2009). Radiolarians and Stratigraphy of Cenomanian-Coniacian Deposits in the Crimean and West Sakhalin Mountains, Pt. 1: Biostratigraphic Subdivision and Correlation. Stratigraphy and Geological Correlation, vol. 17, No. 3, pp. 316-330, ISSN: 08695938

Burollet, P.F. (1956). Contribution a l'étude stratigraphique de la Tunisie centrale. Ann. Mines Geol., Tunis, $\mathrm{n}^{\circ}$ 18, 350p. IVpl, ISSN 03300013

Caron, M., Robaszynski, F., Amédro, F., Baudin, F., Deconinck, J.F., Hochuli, P., Salis-perch nielsen, K. \& Tribovillard, N. (1999). Estimation de la durée de l'événement anoxique global au passage Cénomanien/Turonien. Approche cyclostratigraphique dans la formation Bahloul en Tunisie centrale. Bull. Soc. géol. France, vol. 170, No.2, pp. 145-160, ISSN 0037-9409

Chikhaoui, M. \& Turki, M. (1996). Rôle et importance de la fracturation méridienne dans les déformations crétacée de la zone des diapirs (Tunisie septentrionale). J. Afr. Earth Sci. vol. 21, No. 2, pp. 271-280, ISSN 1464343X

Chikhaoui, M., Turki, M. \& Delteil, M. (1991). Témoignage de la structurogenèse de la marge téthysienne en Tunisie, en Jurassique terminal - Crétacé (région d'El Kef Tunisie septentrional). Geol. Mediterraneenne, vol.XVIII, No. 3, pp. 125-133, ISSN 0397-2844

Cordey, F., Boughdiri, M. \& Sallouhi, H. (2005). First direct age determination from the Jurassic radiolarian-bearing siliceous series (Jedidi Formation) of north-western Tunisia. Comptes Rendus Geoscience, vol. 337, No. 8, pp. 777-785, ISSN 16310713

Danelian, T., Tsikos, H., Gardin, S., Baudin, F., Bellier, J.P.\& Emmanuel, L. (2004). Global and regional palaeoceanographic changes as recorded in the mid-Cretaceous (Aptian-Albian) sequence of the Ionian zone (northwestern Greece). Journal of the Geological Society, vol. 161, No. 4; pp. 703-709, ISSN 00167649

Danelian, T., Baudin, F., Gardin, S., Masure, E., Ricordel, C., Fili, I., Mecaj, T. \& Muska, K. (2007). The record of mid Cretaceous oceanic anoxic events from the Ionian zone of southern Albania. Revue de micropaléontologie, vol. 50, No. 3, pp. 225-237, ISSN 00351598

Danelian, T. (2008). Diversity and biotic changes of Archaeodictyomitrid Radiolaria from the Aptian/Albian transition (OAE1b) of southern Albania. Micropaleontology, 54, No. 1, pp. 3-12, ISSN 00262803

Erbacher, J. (1998). Mid-Cretaceous radiolarians from the Eastern equatorial Atlantic and their paleoceanography. In: Proceedings of the Ocean Program, Scientific Results Mascle, J., Lohmann, G.P., Moullade, M. (Ed.), vol. 159, pp.363-373, ISSN 1096-7451 College Station, TX (Ocean Drilling Program)

Erbacher, J. \& Thurow, J. (1998). Mid-Cretaceous radiolarian zonation for the North Atlantic: an example of oceanographically controlled evolutionary processes in the marine biosphere? In: Geological Evolution of Ocean Basins: Results from Ocean Drilling Program, Cramp, A., Macleod, C.J., Lee, S.V., Jones, E.J.W. (Ed.),. Geological Society, London Special Publications 131, 71-82, ISBN 05852357599780585235752

Heldt, M., Bachmann, M. \& Lehmann, J. (2008). Microfacies, biostratigraphy, and geochemistry of the hemipelagic Barremian - Aptian: Influence of the OAE 1a on the southern Tethys margin. Palaeogeography, Palaeoclimatology, Palaeoecology, vol. 261, No. 3-4, pp. 246-260, ISSN 00310182 
Kariminia, S.M. (2006). Upper Jurassic and Lower Cretaceous radiolaria biostratigraphy of California coast ranges. Ph. D. Thesis, University of Texas, Dallas, $143 \mathrm{pp}$.

Kurilov, D. V. \& Vishnevskaya, V. S. (2011). Early cretaceous radiolarian assemblages from the East Sakhalin Mountains. Stratigraphy and Geological Correlation, vol. 19, No. 1, pp. 44-62, ISSN: 08695938.

Layeb M. \& Belayouni, H. (1989). La formation Bahloul au Centre et au Nord de la Tunisie un exemple de bonne Roche mère de pétrole à fort intérêt pétrolier. Mémoires de l'ETAP, n³, Actes des II ème journées de géologie Tunisienne appliquée à la recherche des hydrocarbures , pp, 489-503, OCLC 32815633, Tunis, Tunisie, Nov - 1989

Layeb, M., 1990. Etude geologique, geochemique et mineralogique, regionale, des facies riches en matiere organique de la Formation Bahloul d'age Cenomano-Turonien dans le domaine de la Tunisie Nord-Centrale. PhD Thesis, Univ. de Tunis II, Tunis, 209 pp.

Layeb, M., and Belayouni, H., 1999. Paléogéographie de la Formation Bahloul (passage Cénomanien - Turonien), Annales des mines et de la géologie, vol. 40, pp. 21-44, ISSN 03300013

Maamouri, A.L., Zaghbib-Turki, D., Matmati, M.F., Chikhaoui, M. \& Salaj, J. (1994). La Formation Bahloul en Tunisie centro-septrentionale: variations latérales, nouvelle datation et nouvelle interprétation en termes de stratigraphie séquentielle. J. Afr. Earth Sci., vol. 18,No.1, pp. 37-50, ISSN 1464343X

Marcucci Passerini, M., Bettini, P., Dainelli, J. \& Sirugo, A. (1991). The "Bonarelli Horizon" in the central Apennines (Italy): radiolarian biostratigraphy. Cretaceous Research, vol. 12, No. 3, pp. 321-331, ISSN 01956671

Martinez C. \& Truillet R. (1987). Évolution structurale et paléogéographie de la Tunisie. Memoria de la Societa Italiana de Geologia, vol. 38, No. 35-45, ISSN 2038-1727

Messaoudi F. \& Hammouda F. (1994). Evènement structuraux et types de pièges dans l'offshore Nord-Est de la Tunisie. Proceedings of the 4 th tunisian petroleum exploration conference, pp. 55-64, OCLC 502635466, Tunis, Tunisia, may 1994).

Michalík, J.,Soták, J., Lintnerová, O., Halásová, E., Bak, M., Skupien, P. \& Boorová, D. (2008). The stratigraphic and paleoenvironmental setting of Aptian OAE black shale deposits in the Pieniny Klippen Belt, Slovak Western Carpathians. Cretaceous research vol. 29, No. 5-6, pp. 871-892, ISSN 01956671

Musavu-Moussavou, B. \& Danelian, T. (2006). The radiolarian biotic response to Oceanic Anoxic Event 2 in the southern part of the Northern proto-Atlantic (Demerara Rise, ODP Leg 207). Revue de Micropaléontologie, vol. 49, No. 3, pp. 141-163, ISSN 00351598

Musavu-Moussavou, B., Danelian, T., Baudin, F., Coccioni, R. \& Frohlich, F. (2007). The radiolarian biotic response during OAE2. A high-resolution study across the Bonarelli level at Bottaccione (Gubbio, Italy). Revue de Micropaléontologie, vol. 50, No. 3, pp. 253-287, ISSN 00351598.

Nederbragt, A. J. \& Fiorentino, A. (1999). Stratigraphy and paleoceanography of the Cenomanian-Turonian Boundary Event in Oued Mellegue, north-western Tunisia. Cretaceous Research, vol.20, No. 1, pp. 47-62, ISSN 01956671

O'Dogherty, L. (1994). Biochronology and paleoecology of Mid-Cretaceous radiolarians from Northern Apennines (Italy) and Betic Cordillera (Spain). Mémoires de Géologie (Lausanne), 21, 415pp, ISSN 1015-3578 
Ouahchi, A., M'Rabet, A., Lazreg, J. Mesaoudi, F. \& Ouazaa, S. 1998. Early structuring, paleoemersion and porosity development: a key for exploration of the aptian serdj carbonate reservoir in Tunisia. Proceedings of the 6th Tunisian petroleum exploration and production conference, pp.267-284, Tunis, Tunisia, May 5th - 9th, 1998, OCLC 704163368

Palechek, T. N., Savel'ev, D. P. \& Savel'eva, O. L. (2010). Albian-Cenomanian Radiolarian Assemblage from the Smaginsk Formation, the Kamchatskii Mys Peninsula of Eastern Kamchatka. Stratigraphy and Geological Correlation, vol.18, No. 1, pp. 63-82, ISSN: 08695938

Premoli Silva, I., Erba, E., Salvini, G., Locatelli, C. \& Verga, D. (1999). Biotic changes in Cretaceous oceanic anoxic events of the Tethys. Journal of Foraminiferal Research, vol.29, No.4, pp. 352-370, ISSN: 00961191.

Racki, G. \& Cordey, F. (2000). Radiolarian palaeoecology and radiolarites: is the present the key to the past? Earth-Science Reviews, vol.52, No.1-3, pp. 83-120, ISSN 00128252

Robaszynski, F., Zagrarni, M.F., Caron, M. \& Amédro, F. (2010). The global bio-events at the Cenomanian-Turonian transition in the reduced Bahloul Formation of Bou Ghanem (central Tunisia). Cretaceous Research, vol.31, No.1, pp. 1-15, ISSN 01956671

Saadi, J., (1990). Exemple de sédimentation syntectonique au Crétacé inférieur le long d'une zone de décrochement NS. Les structures d'Enfidha (Tunisie nord-orientale). Géodynamique, vol.5, No. 1, pp. 17-33, ISSN 0766-5105

Saadi, J., (1991). Sedimentation en zone mobile coulissante, l'exemple du Cretace inferieur des structures submeridiennes de la region d'Enfidha. (Prolongement septentrional de l'Axe N.S-Tunisie nord-orientale). PhD Thesis, Université de Pau,244 pp.

Saïdi, M. \& Belayouni, H. (1994). Etude géologique et géochimique des roche mères albovraconienne dans le domaine de la Tunisie centro-septentrional. Proceeding of the 4th Petroleum Exploration Conference, No. 7, pp. 91-116, OCLC 502635466, Tunis, Tunisia, may 1994

Salvini, G. \& Marcucci Pesserini, M. (1998). The radiolarian assemblages of the Bonarelli Horizon in the Umbria-Marches Apennines and Southern Alps, Italy. Cretaceous Research, vol. 19, No. 6, pp. 777-804, ISSN01956671

Scopelliti, G., Bellanca, A., Coccioni, R., Luciani, V., Neri, R., Baudin, F., Chiari, M. \& Marcucci, M. (2004). High-resolution geochemical and biotic records of the Tethyan "Bonarelli Level" (OAE2, Latest Cenomanian) from the Calabianca-Guidaloca composite section, northwestern Sicily, Italy. Palaeogeography, Palaeoclimatology, Palaeoecology, vol. 208, No. 3-4, pp.293-317, ISSN 00310182

Ślączka, A., Gasiñski, M. A., Bąk, M. \& Wessely, G. (2009). The clasts of Cretaceous marls in the conglomerates of the Konradsheim Formation (Pöchlau quarry, Gresten Klippen Zone, Austria). Geologica Carpathica, vol. 60, No. 2, pp. 151-164, ISSN 13350552

Smrečková, M. (2011). Lower turonian radiolarians from the locality Červená Skala section. Mineralia Slovaca 43, 31-38, ISSN 0369-2086

Soua, M., Zaghbib-Turki, D. \& O’Dogherty, L. (2006). Les réponses biotiques des radiolaires à l'événement anoxique du cénomanien supérieur dans la marge sud téthysienne (tunisie). Proceedings of the 10th tunisian petroleum exploration $\mathcal{E}$ production conference. pp. 195-216. 
Soua M. \& Tribovillard, N. (2007). Modèle de sédimentation au passage Cénomanien /Turonien pour la formation Bahloul en Tunisie. Comptes Rendus Geoscience, vol. 339, No. 10, pp. 692-701, ISSN 1631-0713

Soua, M., Echihi, O. Herkat, M., Zaghbib-Turki, D., Smaoui, J., Fakhfakh-Ben Jemia, H. \& Belghaji, H. (2009). Structural context of the paleogeography of the Cenomanian Turonian anoxic event in the eastern Atlas basins of the Maghreb. C. R. Geoscience, 341, No. 12, pp. 1029-1037, ISSN 1631-0713

Talbi, R. (1991). Etude géologique et géochimique des faciès riches en matière organique d'âge Albien du bassin de Bir M'Cherga (NE de Tunisie) : déterminisme de leur genèse et intérêt pétrolier de la région. PhD Thesis, University de Tunis, 223 pp.

Thurow, J. (1988). Cretaceous Radiolarians of the North Atlantic Ocean: ODP Leg 103 (Sites 638, 640 and 641) and DSDP Legs 93 (Site 603) and 47B (Site 398). In: Proceedings of the Ocean Drilling Program, Scientific Results, Boillot, G., Wintere, E.L., et al. (Ed.). Proceedings of the Ocean Drilling Program, Scientific Results, 103, 379 -418, ISSN 0884-5891.

Turki, M.M. (1985). Polycinematique et contrôle sédimentaire associé sur la cicatrice Zaghouan-Nebhana. Ph.D. thesis, Univ. Tunis, 252 pp. 


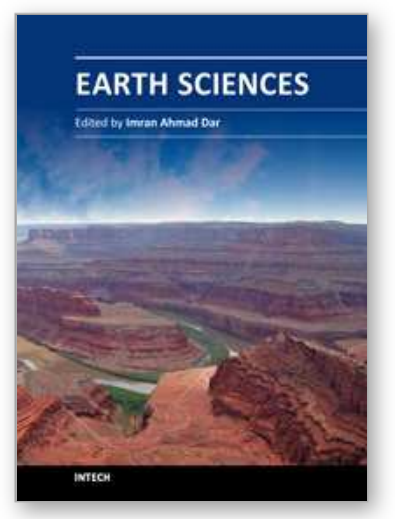

\author{
Earth Sciences \\ Edited by Dr. Imran Ahmad Dar
}

ISBN 978-953-307-861-8

Hard cover, 648 pages

Publisher InTech

Published online 03, February, 2012

Published in print edition February, 2012

The studies of Earth's history and of the physical and chemical properties of the substances that make up our planet, are of great significance to our understanding both of its past and its future. The geological and other environmental processes on Earth and the composition of the planet are of vital importance in locating and harnessing its resources. This book is primarily written for research scholars, geologists, civil engineers, mining engineers, and environmentalists. Hopefully the text will be used by students, and it will continue to be of value to them throughout their subsequent professional and research careers. This does not mean to infer that the book was written solely or mainly with the student in mind. Indeed from the point of view of the researcher in Earth and Environmental Science it could be argued that this text contains more detail than he will require in his initial studies or research.

\title{
How to reference
}

In order to correctly reference this scholarly work, feel free to copy and paste the following:

Ben Fadhel Moez, Soua Mohamed, Zouaghi Taher, Layeb, Mohsen, Amri Ahlem and Ben Youssef Mohamed (2012). Radiolarian Age Constraints of Mid-Cretaceous Black Shales in Northern Tunisia, Earth Sciences, Dr. Imran Ahmad Dar (Ed.), ISBN: 978-953-307-861-8, InTech, Available from:

http://www.intechopen.com/books/earth-sciences/radiolarian-age-constraints-of-mid-cretaceous-black-shalesin-northern-tunisia

\section{INTECH}

open science | open minds

\section{InTech Europe}

University Campus STeP Ri

Slavka Krautzeka 83/A

51000 Rijeka, Croatia

Phone: +385 (51) 770447

Fax: +385 (51) 686166

www.intechopen.com

\section{InTech China}

Unit 405, Office Block, Hotel Equatorial Shanghai

No.65, Yan An Road (West), Shanghai, 200040, China

中国上海市延安西路65号上海国际贵都大饭店办公楼405单元

Phone: +86-21-62489820

Fax: $+86-21-62489821$ 
(C) 2012 The Author(s). Licensee IntechOpen. This is an open access article distributed under the terms of the Creative Commons Attribution 3.0 License, which permits unrestricted use, distribution, and reproduction in any medium, provided the original work is properly cited. 